\title{
CALL FOR PROFESSIONAL JUDGMENT POLICY AND ACCOUNTING ESTIMATES CHANGES WITHIN PUBLIC INSTITUTIONS
}

\author{
Iuliana Cenar ${ }^{1}$
}

\begin{abstract}
Professional accountants have an important role in society, moreover that they can be distinguished from other professions by assuming responsibility to the public. Policies and accounting estimates require the call for professional judgment to identify the moment of their change, of broad implications and transmission of induced effects on users. This paper deals with aspects related to the importance of professional judgment, its need in accounting, including the case of policies and accounting estimates changes, the provisions of national and international regulatory framework and, in this regard, possibilities for implementing changes and presenting information.
\end{abstract}

Key words: professional judgment, accounting policies changes, estimates accounting changes, public institutions

JEL Codes: $M 41$

\section{Introduction}

"Nothing is more difficult, and therefore more precious, than to be able to decide." (N. Bonaparte, after Horomnea, 2011).

Naturally, the thought leads us to management, to those who are at the forefront in terms of decisions, to managers. In any field, however, it is about a transfer of values, the constant fluctuation of some property items, wealth and interest due to amplification of human needs and decreasing resources.

Thus, the need for accounting. Why? Because "beyond any doubt and imperfections, accounting is closer to the truth than any other economic information system because it keeps record, quantifies, processes and communicates specialized information to a clearly defined market users (Horomnea and Rusu, 2009).

Complementary, in accounting there is a fundamental objective (true image), one can identify several options for achieving the objectives and accounting options for one of the achievement possibilities are shaped by professional accountants' input and by professional judgment. Thus, the three elements involved by managerial decision (Nicolescu, 2007) are also found in accounting. Obviously, the decision maker, the professional accountant should ensure that he made an appropriate selection of principles, bases, conventions, rules and practices applied in preparing and presenting financial statements, that he made the best estimates, in other words, he met the judgement requirements in terms of decision making.

On this contextual background, we justify the importance of cohabitation of professional accountant with decision making factors at the organizational level, the need for call for professional judgment and some ways to exercise it within public institutions in terms of policies and accounting estimates changes, determining the effects and the way of presenting the information in the explanatory notes to the financial statements.

\footnotetext{
${ }^{1}$ „1 Decembrie 1918” University of Alba Iulia, e-mail: cenar_iuliana@uab.ro
} 


\section{Literature review}

The issue of professional judgment and exercising it in accounting to support decision making process is gaining more and more ground in literature. Information valences of accounting should be retrieved and exploited in an integrated communication process that, beyond legal framing patterns must be consistent with management systems and internal control, with the external environment and strategic orientations background.

The quality of accounting information depends essentially on the exercise method of professional judgment. Logic circuit of any human action found in the fundamental functions of management process can only be carried out successfully on the basis of relevant information, received in time and accessible representation of specialized staff (Leustean, 2012).

As a field of activity, accounting competes with other domains and occupations, so that "it is important for accounting profession to have good looks, respectable, to be seen as raising challenges and offering rewards to attract the best professionals" (Albu, 2012).

The existence of a research object, of specific methods and justification of social utility, give accounting the status of science, but it "is not an exact science, because obtaining relevant information requires making judgement for each case" (Istrate, 2004, taken after Mihalciuc, 2006).

Accounting uncontested advantage is that it provides an "overview that is preferable to a multitude of individual views (Meyer, cited by Horomnea and Socea, 2011). In addition, "a performing modern management appeals to accounting information offer" (Horomnea, 2011).

The information allows the reduction of uncertainty and complexity of actions facilitates elections, highlighting the possibilities and limitations of alternative solutions. The assumption of perfect knowledge is illusory, for technical and economic reasons.

Where there is freedom and compliance, professional judgement must be present. And this, even more as "accounting is a model of reality representation, but legal, economic and other nature reality, forming the enterprise or other organization which changes constantly" (Ionascu, 1997).

Therefore, professional judgment and the experience of those issuing accounting information have priority over accounting standardization, based on principles and conventions which must not be raised to a dogma rank, but considered an evolutionary theoretical ensemble (Ionascu, 1997), conduct rules of professional accountant (Pop, 2002), basic elements in accounting ethics".

Indirectly, the need for professional judgment was justified by "the presence of many options in a country's accounting referential, as is the presence of several references in the accounting system of a country ... the diversity of accounting policies and estimation techniques" that "can to create a state of quasi-anarchy with serious consequences on decision making process " (Feleaga and Malciu, 2002).

IPSAS 3 "Changes in accounting policies, accounting estimates and errors" deals with the change in policies and accounting estimates in the following aspects: the circumstances that cause changes, the elements constituting or not changes in policies / accounting estimates, the application method of changes (retrospective and prospective, or prospective), the information to be presented in the financial statements.

For public institutions, national accounting law is very stingy in providing information on policy and accounting estimates changes.

Thus, according to the framework law in accounting (Accounting Law no. 82/91, updated) annual financial statements must be accompanied by a written statement of authorizing officers confirming that the accounting policies used in preparing the annual financial statements are in compliance with applicable accounting regulations. The provision is justified if we consider that through the mentioned legislative act, an outline for accounting organization and management is drawn.

In our opinion, this is not so if we consider the regulatory framework on the accounting organization and management within public institutions (OMFP 1917/2005) which makes (only!) 
the following remarks: "Changes in accounting policy are permitted only if required by law or have as a result more relevant or reliable information regarding the operations of the public institution. This should be mentioned in the explanatory notes."

Ghe. Popescu explains the necessary judgment and appropriate accounting treatments to meet the quality requirements of accounting information provided by the national and international accounting references: implications of using a particular stock assessment methods, the effects of quantization the residual value of fixed assets, accounting treatment for recognizing indebtedness costs, capital maintenance concept and influence in earnings recognition in income accounts.

Different accounting models display different degrees of relevance and reliability and, as in other areas, management must seek a balance between relevance and reliability.

By extrapolation, based on the idea expressed by I. Ionascu, we consider appropriate the innovative and critical manner of approaching "accounting realm" to avoid dogmatism in accounting thought, by forming a unique scheme of accounting theory (Ionascu, 2003).

After all, an accounting standard is a technical element that has a cultural component that stood in its elaboration, but it is appropriate to the cultural context in which it operates.

The mentioned circumstances make obvious the importance of accounting profession and the exercise of professional judgment to not adversely affect decision making process.

Based on these aspects to which we add reconsidering the role and importance of the accounting profession, the importance exercised by accounting on social environment, we identified as opportunities to undertake a research that promotes professional judgment in accounting reality representation process in which accounting conventions and rules are also involved. Our benchmark was the changing of policies and accounting estimates in terms of identifiability, permissiveness, of the application and effects presentation method in financial reporting.

\section{Research methodology}

The research undertaken falls within the category of fundamental research, of inductive type and aims at developing a theoretical approach on intervention of professional judgment in the matter of policy and accounting estimates changes in the public entities. As research techniques we used literature review, analysis of the national legal framework on policies and accounting estimates, and of international accounting standards specific to the public sector, the study of the documents on the investigated subject in the public institutions.

The scientific approach is positivist, the research being oriented towards accounting field reality as specific structure, formulating explanations for the valences of professional judgment and policy and accounting estimates changes, implications arising from the presentation of information which are then post-factual analysed in public institutions practice in order to improve accounting practice.

In terms of finality, the research is both explanatory (as data collection method, document analysis being used) and exploratory, of investigation of the role and necessity of professional judgment in the action of amending policies and accounting estimates, using participatory observation.

\section{Results and discussions}

\section{The need for professional judgment in accounting}

The concern to achieve the primary objective of accounting - the fair view in order to help decision makers requires the call for professional judgment and thus, making decisions regarding the use of an accounting treatment or another.

The bearers of professional judgment are professional accountants, which, like human society as a whole can not avoid the idea of order, discipline and prediction in economic terms. 
These "priests of the accounting ritual" are called to contribute significantly to a climate of confidence between different actors ... and to provide insurance to increase confidence in the financial information (Botez, 2005).

Modern accounting is characterized by the fact that policies in this field tend to be increasingly complex which requires that the call for professional judgment to become an indispensable condition (Brabete, 2011).

Recent studies (Albu, 2012) reveals that the accountant's image has certain nuances in terms of social groups, thus, for students, the profession is more prestigious and ethic, for professionals it requires flexibility and creativity, oriented towards profit and towards support in decision making. For managers this is an analyst and a consultant.

The profile of a good professional in public institutions accounting is outlined from elements such as: knowledge of accounting reform in the field with all its thickets, understanding and application of International Accounting Standards specific to public sector, awareness of the importance and magnitude of applying professional judgment, management responsible counselling in establishing accounting policies, following professional ethics rules etc.

Professional judgment is based on theoretical knowledge, on ethical behaviour, on specific skills, on combination and bonding of good practice information, resultant vector adding value to performance indicators, translated into effective management of public financial resources and a high quality level of public services.

The above mentioned issues lead us to the conclusion that also in the process of obtaining accounting information the decision is necessary, including that on an accounting policy change or revision of an estimate. Why? Because it is a process that always involves the option of choice, with assuming responsibility towards the users.

\section{Implications in policies and accounting estimates changes}

Quite naturally, in the evolution of any entity there are changes, transformations inherent to the evolutionary process manifested in any field or segment of activity. In what the accounting policy changes are concerned, these may be applied either prospectively or retroactively.

Retroactive restatement of an accounting policy requires to correct the recognition, measurement and disclosure of amounts of elements of financial statements as if a prior period error had never existed. Also known as retrospective restatement (Feleagă, 2007) the change in the accounting policy results either from applying a standard which does not include transitional provisions or as a result of management decision makers (voluntary change). The entity shall adjust the opening balance of each affected component of net equity for the earliest period presented and other comparative amounts disclosed for each prior period that has been presented.

A change in the accounting policy should be made in one of the following cases (IPSAS 3, p. 17):

- It is required by an international public sector accounting standard,

or

- Results in the financial statements providing reliable and more relevant information about the effect of transactions, other events and conditions of the entity's financial position, financial performance or cash flows - voluntary change.

The figure below shows the events or transactions that represent or do not represent changes in accounting policies (fig. no. 1): 


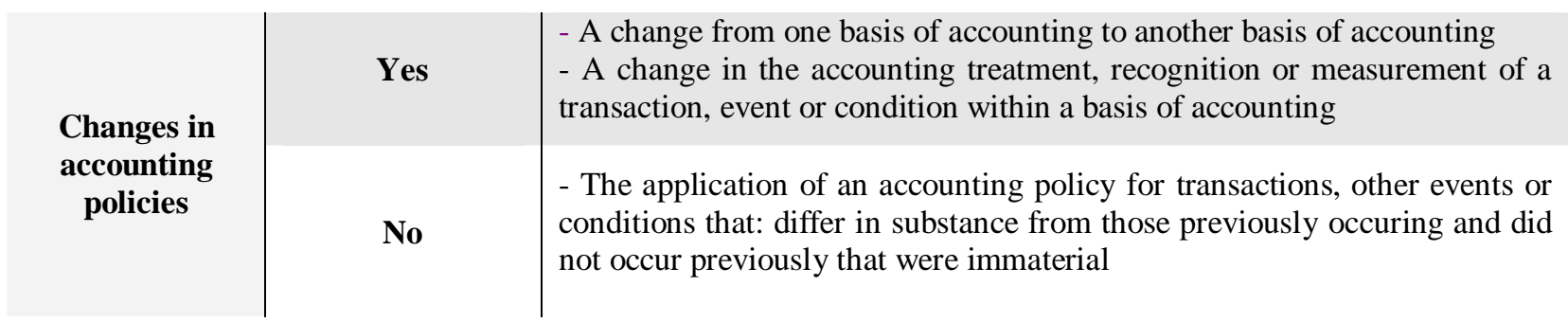

Figure no. 1. - Placing events according to the changes that occur in accounting policies

Retrospective application of an accounting policy change is not possible if you can not determine the specific, cumulative effect, of change on comparative information for one or more presented prior periods. In this assumption, the new accounting policy is applied to the book values of assets and liabilities from the beginning of the initial period for which retrospective application is possible (can be the current period).

The adjustment of comparative information for the prospective application of the new accounting policy, from the earliest date possible, is necessary when you can not determine the cumulative effect at the beginning of the current period to apply the new accounting policy to all prior periods (in other words, when retroactive application is impossible).

For example, the change in accounting policy for the treatment of indebtedness costs. In the periods prior to year $\mathrm{N}$, the public institution capitalized indebtedness costs directly attributable to the construction of a security system, not completed yet. At present, the institution management believes that recognition of expenses of indebtedness costs provides a more transparent treatment of financial costs and it is also in compliance with the filed practices, which improves comparability feature of information from the financial statements.

In the previous years, the entity capitalized for financial year $\mathrm{N}-1$ indebtedness costs amounting to RON 130,000 and RON 260,000 in the previous periods.

In year $\mathrm{N}$, the public institution has a patrimonial surplus (without considering interest costs of RON 150,000) worth RON 1,500,000. At the end of the previous financial year, the patrimonial surplus (closing accumulated surplus) was worth RON 1,900,000 and RON 1,000,000 at the beginning (opening accumulated surplus).

The components of net assets are as follows: RON 5.000.0000 funds, proprietary surplus 150,000 RON.

In the patrimonial income statement (financial performance situation according to IPSAS) the result restated for the year $\mathrm{N}$ is (900.000-130.000) $=$ RON 770,000.

The situation of restated net assets/equity is as follows (table no. 1):

Table no. 1.

The situation of restated net assets

\begin{tabular}{|l|r|r|}
\hline \multicolumn{1}{|c|}{ Elements } & \multicolumn{1}{c|}{ Funds } & \multicolumn{1}{c|}{ Result (surplus) } \\
\hline Balance at 31.12.N -2 - previous reports & $5,000,000$ & $1,000,000$ \\
\hline Changes in accounting policies - interest capitalization & - & $(260,000)$ \\
\hline Balance at 31.12.N -1 - after restatement & $5,000,000$ & 740,000 \\
\hline Surplus at 31.12.N-1 & & 770,000 \\
\hline Balance at 31.12.N-1 & $5,000,000$ & $1,510,000$ \\
\hline Surplus at 31.12.N & & $1,350,000$ \\
\hline Balance at 31.12.N & $5,000,000$ & $2,860,000$ \\
\hline
\end{tabular}

In the notes to the financial statements there are required claims on the fact that the entity has changed its accounting policy on the treatment of indebtedness costs. 
In previous periods, they were capitalized, but now the requirements of comparability, credibility and relevance with a more transparent cost treatment require settlement as expenses of indebtedness costs.

Furthermore, it should not be omitted to specify the way in which the change in accounting policy has been accounted for and that the financial statements for the previous financial year have been restated, as well as the restatement effects, as follows:

- the effect on the financial year $\mathrm{N}$

a. the increased of financial costs with RON 130,000 and therefore

b. reducing heritage surplus with RON 130,000;

- the effect on the periods prior to year $\mathrm{N}$

a. reducing heritage surplus with RON 260.000.

The final result of the change in accounting policy, retrospectively applied was a decrease in operating assets during construction and accumulation of a surplus of RON 390,000.

According to the example, the surplus / excess accumulated by the opening representing the value adjustments on the period prior to year N-1 was reduced by RON 260,000.

In the second case, the change in accounting policies determines the implications presented as follows (fig. no. 2):

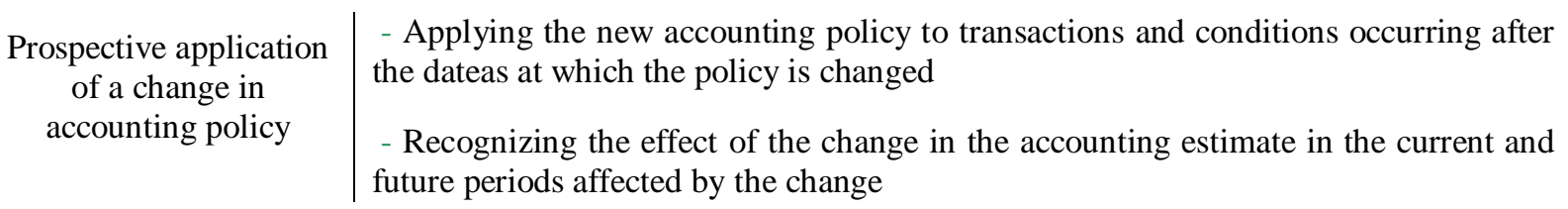

Figure no. 2. - Prospective application of a change in accounting policy

The prospective change in accounting policies and the produced effect is presented in the explanatory notes to the financial statements.

The change in accounting policy on depreciation of fixed assets of a public institution, with the purpose of the transition to a component-based approach, possible from a technical study ordered in this regard. This provides information on the components of fixed assets, the fair values of components, useful lifespan, the depreciable and remaining value at the beginning of year $\mathrm{N}$. The impossibility to retroactively address the change in accounting policy is that technical study was not a sufficient basis for reliable estimates of component costs, which were not separately accounted for in advance and neither the existing records permitted the reconstruction of information. Accounting approach of a prospective change at any time prior to year $\mathrm{N}$ is not possible in these circumstances, but this is necessary starting with the current period as a result of the transition from cost model to revaluation.

Assuming that the following existing data: net book value RON 77,000 (cost of fixed assets 175,000, amortization RON 98,000), depreciation prospective expenses (the old base) RON 10,500 for the year $\mathrm{N}$ are completed at the beginning of the year with further information, ie the fair value at RON 119,000, estimated residual value RON 21,000, average remaining lifespan of 8 years and therefore depreciation expenses (the new base) RON 12,250. In the explanatory notes, the induced effects should be mentioned. Thus, the book value of fixed assets increased by RON 42,000, with 1,750 RON depreciation expenses and revaluation reserves of RON 42,000 were created.

National regulatory framework for accounting of public institutions, as we have said, deals with the issue at the level of need and permissiveness and not in terms of the presentation of the implications arising from the changes in accounting policies.

Accounting practice revealed a fair acquisition (but not welcome in our opinion) of the regulatory specifications but not exploiting the possibilities to choose an accounting policy or another, to justify its modification and overall effects, to present them in the explanatory notes to the financial statements, in other words, to value the potential of professional judgment exercise. 
In general, the estimate is seen as approximate setting of the value of a good (according to the dictionary), of a liability (our emphasis). Accounting estimates involve judgments based on the latest available information and are an important element of financial statements.

According to International Standards on Auditing, "accounting estimates" means an approximation of the value of an element in the absence of precise means of assessment. There are mentioned as examples: "deferred taxes; provisions for loss from a lawsuit; losses on construction contracts in progress; provisions for guarantees satisfaction".

Purpose of an estimation technique is to set monetary amount assigned a valuation bases, so it is important that it be reliable and accurate approximate a larger, subject to the constraint imposed by the cost - benefit (Gîrbina, 2008).

Accounting estimates may be determined as part of routine accounting system that operates continuously or may be out of routine, operating only at the end of the period. In many cases, such as using standard depreciation rates for each category of fixed assets, accounting estimates are made based on experience. In such cases, the formula should be regularly reviewed by management. Compared to the previous example, revision may require revaluation of the remaining useful lifespan of the assets or comparing current results with the estimate and adjusting the formula when necessary.

Thus, the changes produced in the circumstances on which they were based, the emergence of new information and further experience lead to the need to review accounting estimates which may refer to various budgetary revenues, irrecoverable budgetary debts, the wearing of material current assets, the fair value of assets and financial liabilities, useful lifespan of depreciable assets etc.

Revision of accounting estimates is unrelated to previous periods, so it can affect either surplus / deficit of the current period, or that of the current period and the following. In the first case it can be a variation of the value of irrecoverable budgetary debts, and in the second case, by changing the estimated useful lifespan or the manner provided for consumption of economic benefits or potential service embedded in depreciable assets. Re-estimating the residual value falls in the same category.

At the opposite end, there are accounting errors, produced as a result of non-use or misuse of reliable information that was available when financial statements were authorized for issue and could reasonably be expected.

Correcting errors is different from the change in estimates, which by their nature are "approximations that have to be revised when additional information becomes known" (Gîrbină, 2008). Therefore patrimonial surplus or deficit for the period in which the error occurred is not affected by its correction, which is realized in the comparative information for the period in which it occurred by adjusting the reported result of the earliest period presented in the financial statements.

When reviewing accounting estimates the same position in the patrimonial result account is affected.

The management is responsible for making accounting estimates included in the financial statements. They are often made in conditions of uncertainty regarding the outcome of events that have occurred or may occur and involve professional judgment.

Any entity should disclose, in the financial statements, information about the significant estimates of future periods and other important sources of uncertainty at the balance sheet date, that having a high risk of generating an adjustment to the book value of assets and liabilities within the next financial year. This information should include the nature of the estimates and their book value at the balance sheet date.

Policy and accounting estimates changes are related to professional accountant's perception on the problem and the need to solve it, of the use of relevant information to the analysis of the effects in terms of size and possible alternatives, and of selection criteria that was used in conducting elections. 
Paradoxically, perhaps the national legislation on public institutions accounting makes no statement on the accounting estimates and the possibility of amending them. Shall we ask why in these circumstances the residual value of fixed assets is zero, why there are incorporated no provisions and adjustments for depreciation or loss of value in accounting practice of public institutions?

Equally paradoxically, we think so, we must ask ourselves. Why? Just from the need to exercise professional judgment. As long as the regulatory framework enables estimations, as long as accounting theory and international accounting referential deal with this issue in detail, we do not see why we should not exploit valences of professional judgment.

\section{Conclusions}

Although the circumstances are specified (but not time) in which changes in accounting policies are allowed, the regulatory framework does not refer to the necessity of their justification in the explanatory notes of the financial statements (when the change was determined by the initiative of the public entity). This way users can assess whether the new accounting policy has been properly chosen, the effect thereof on the results for the reported period and the following ones.

Also, neither the accounting estimates nor the risk of confusion between their changes and the accounting policies have been addressed. Estimates occur when some elements of the annual financial statements cannot be accurately measured (bad debts, inventory obsolescence, useful life as well as the expected pattern of consumption of future economic benefits embodied in depreciable assets, etc). It implies judgments based on latest and most reliable available information. When it is difficult to distinguish between two elements, it subsequently arises the "priority" treatment as a change in an accounting estimate.

A difficult transition from rigid legal patterns to the exploitation of accounting information valences passed through a professional judgment filter lies in the lack of specifications regarding accounting choices.

The existence of rigid rules does not prevent the professional accountant from conducting elections. He has, for describing the facts, a margin of freedom that can lead him at a subjective interpretation of them. Also, complex estimates involve a high degree of specialized knowledge and professional judgment.

Thus, proper regulation of how to approach policies and accounting estimates changes is required. This, however, is not sufficient to ensure the transparency of accounting information, indispensable element in public institutions survival competition and ensuring the efficiency of the system translated through human art to lead and public affairs management, through the set of rules by which a public institution is managed and controlled.

We believe that, in order to create information, we should not limit ourselves to rules and definitions which, sooner or later, are doomed. Professional accountant's role on the accounting stage is to refine and adapt a universal theoretical scheme to a specific context, to make choices based on a high degree of competence and professional value.

Valuing professional judgment in accounting, including the option of accounting policies and the use of more realistic approximations, becomes all the more pressing with both accounts, in addition to a tool quality that provides the information function achievement and decision-making process assistance, it is an important factor of influence of socio - economic environment.

\section{References}

1. Albu N., 2012. Imaginea si rolul contabilului în Romania - rezultate empirice si implicatii pentru profesie, Contabilitatea, expertiza si auditul afacerilor Review, no. 1/2012, pp. 6-11

2. Botez D., 2005. Tendinte actualitati si perspective ale profesiunii contabile din Romania, Iasi, Sedcom Libris Publishing House, pp. 9, 26 
3. Brebete V., 2011. Contabilitatea intre traditional si modernism, Contabilitatea, expertiza si auditul afacerilor Review, no. 10, p. 18- 19

4. Feleaga L., Feleaga N., 2007. Contabilitate financiara o abordarea europeana si internationala, vol. II, Economica Publishing House, Bucharest, p. 48

5. Feleaga N., Malciu L., 2002. Politici si opțiuni contabile, Economica Publishing House, Bucharest, pp. 18

6. Horomnea E., 2011. Dimensiuni stiintifice, sociale si spirituale in contabilitate, Iasi, Tipo Moldova Publishing House, p. 22

7. Horomnea E., Rusu, G.A., 2009. Criza financiara globala si perspectivele profesiei contabile intr-o noua abordare, Contabilitatea, expertiza si auditul afacerilor Review, no. 12

8. Horomnea E, Socea A.D., 2011. Consideratii privind rolul managerului si al informației contabile în procesul decizional, Contabilitatea, expertiza şi auditul afacerilor Review, no. 9 , p. 25

9. Horomnea E, Socea A.D., Consideratii privind rolul managerului si al informatiei contabile in procesul decizional, Contabilitatea, expertiza si auditul afacerilor Review, no. 10, p. 6

10. Girbina M.M., Bunea St., 2008. Sinteze, studii de caz si teste grila privind aplicarea IAS (revizuite) - IFRS, Bucharest, CECCAR Publishing House, p.132

11. Ionaşcu I., 1997. Epistemologia contabilitatii, Bucharest, Economica Publishing House, p. 136

12. Ionaşcu I., 2003. Dinamica doctrinelor contabilitatii contemporane, Bucharest, Economica Publishing House, p. 118

13. Leustean D, 2012. Rolul profesionistului contabil in activarea factorilor de progres, Contabilitatea, expertiza şi auditul afacerilor Review, no. 4, p. 6.

14. Mihalache S.C., 2005. Aspecte privind informatiile si deciziile contabile (Some aspects concerning accounting informations and accounting decisions), Analele stiintifice ale Universitatii „Alexandru Ioan Cuza” din Iasi, Tomul L/LI, Stiinte Economice, 2004/2005, available online at http://anale.feaa.uaic.ro/anale/resurse/26\%20Mihalache\%20SCAspecte\%20privind\%20informatiile\%20si\%20deciziile\%20contabile.pdf (12.09.2012), pp. 186-192

15. Mihalciuc C., 2006. Rolul contabilului în organizarea întreprinderii moderne performante, Annales Universitatis Apulensis Series Oeconomica, no. 8/2006, vol. 1, available online at http://www.oeconomica.uab.ro/upload/lucrari/820061/17.pdf (28.08.2012), pp. 187

16. Nicolescu O., Verboncu I., 2007. Managementul organizatiei, Bucharest, Economica Publishing House, p. 208

17. Pop A., Contabilitatea financiara romaneasca armonizata cu directivele europene si cu Standardele Internationale de Contabilitate, Intelcredo Publishing House, Deva, 2002, p. 16

18. Popescu Gh., Principiul prudenței - baza raționamentului profesionistului contabil, Annales Universitatis Apulensis Series Oeconomica, no. 8/2006, vol. 1 available online at http://www.oeconomica.uab.ro/upload/lucrari/820061/23.pdf.

19. Federatia Internationala a Contabililor (2009). Manual de standarde internationale de contabilitate pentru sectorul public, CECCAR Publishing House, Bucureşti.

20. Standardul Internațional de Audit 540, Auditul estimarilor contabile, Audit financiar 2006, Irecson Publishing House, Bucureşti, 2007.

21. ***, Accounting law no. 82/1991 republished, Official Gazette no. 454 of 10.01.2008, with the following changes and.

22. ***, The order of the Ministry of the Public Finance no. 1917/2005 for the approval of the Methodological norms regarding the organization and the management of the accounting of the public institutions patrimony, of the accounts plan for the public institutions and the monograph regarding the registration in accounting of the main operations, Official Gazette no 1186bis/ 2005, with the following changes and. 